\title{
Effect of two agro-ecological zones on insect species of cowpea (Vigna unguiculata L.) Walp during the late cropping season, Delta State, Southern Nigeria
}

\author{
E.O. Egho \\ Department. of Agronomy, Faculty of Agriculture, Delta State University, Abraka
}

\begin{abstract}
The study was conducted in two agro-ecological zones to identify and compare insect species associated with cowpea (Vigna unguiculata (L.) Walp Delta State during the late cropping season of 2005. Asaba in Oshimili South Local Government Area of Delta State lies in the northern drier part of Delta State, south Nigeria while Abraka in the same state is located in the south and experiences a more humid weather. Both locations are about 135 kilometres apart. The results showed that the occurrence and distribution of insect species followed different trends. There were 10 insect orders, 24 families and 39 species in Asaba while Abraka recorded 8 insect orders, 23 families and 35 insect species. The heteroptera with relative abundance of $28.2 \%$ were the dominant species at Asaba, while coleoptera (28.6\%) were the most dominant species at Abraka in the late season. Orthoptera (8.6\%) were slightly more at Abraka than Asaba with $5.1 \%$ relative abundance. Nine insect species recorded at Asaba were absent at Abraka. Conversely, four insect species on the crop at Abraka were absent in Abraka. Ootheca mutabilis Sahl, Aphis craccivora Koch, Megalurothrips sjostedti Trybom, Maruca vitrata Fab and coreid bugs such as Clavigralla tomentosicollis Stal, Anoplocnemis curvipes Fab, C. shadabi Doll, Aspavia armigara Fab, Nezara virudula, Mirperus jaculus were the key insect pests in the study areas. More insect species occurred in Asaba compared to Abraka.
\end{abstract}

Keywords: Cowpea, insect species, late cropping, Asaba/Abraka, southern Nigeria.

\section{INTRODUCTION}

One of the major food crops extensively and intensively grown in Africa for the benefits of man is the legume cowpea (Vigna unguiculata (L). Walp). It is cultivated in the tropical and subtropical regions. The crop serves various purposes: its grain are consumed by man as cheap plant protein (IITA, 1984) since fish, meat, milk and egg proteins are fast disappearing from his table (Alabi et al., 2003). Its young green succulent pods are eaten as vegetable in some African communities (BittenBender et al., 1984) and also as cover crop in farms that have erosion problem (Okigbo, 1978). Other uses are in the areas of restoration of soil fertility, fibre production (Rachie, 1985) and formulation of feeds in industries for livestock when mixed with cassava (Job et al., 1983).

Demand for the crop is therefore ever increasing. Unfortunately, this demand cannot be met because of certain production constraints, among which are the activities of insect pests which largely, are responsible for very low yields in Africa (Taylor, 1964). It is now obvious that various insect pests attack and damage the crop at various stages of growth (Jackai et al., 1988). Insects which have been clearly identified as major cowpea pests are the foliage beetle,
Ootheca mutabilis Sahl., the cowpea aphid, Aphis craccivora Koch, the flower bud thrips, Megalutrothrips sjostedti Tryomb, the legume pod borer, Maruca vitrata Fab and a complex of pod sucking bugs among which are Clavigralla tomentosicollis, Anoplonecmis curvipes, Aspavia armigera (Jackai and Daoust, 1986). Cowpea production is carried out in the Northern savannah regions of Nigeria where the crop thrives under optimum conditions and usually grown on a large scale (Emosairue et al., 2004). Recently however, the cultivation of the crop has spread to the South and is now grown by many farmers in the West and East of southern Nigeria (Ejiga, 1979; FOS, 1995). Insect species are associated with the crop wherever cowpea is cultivated but not all species occur in all regions, the species vary from locality to locality (Singh and Jackai, 1985).

This study focuses on insect species in the late cowpea cropping season in Asaba and Abraka. It is to report locational effect on cowpea insect species, noting similarities and differences in species.

\section{MATERIALS AND METHODS}

The trials were carried out during the late cropping season of 2005 in two widely apart agroecological zones - Asaba and Abraka, (both in the 
rain forest zone) in Nigeria. Asaba lies in the Northern part of Delta State and experiences drier climatic condition than Abraka, located in the south and closer to the riverine region of Delta State.

At Asaba, the trial was conducted in the Teaching and Research Farms of the Agronomy Department of the Delta State University. At Abraka, the study took place on a public land half a kilometre to the main campus, Delta State University. The land in both locations were hand tilled. The experimental cowpea plot size was $5 \mathrm{~m}$ $x 3 \mathrm{~m}$ with $1.5 \mathrm{~m}$ between plots. The cowpea seeds planted were Ife brown. Three seeds were planted per hole at planting spacing of $60 \mathrm{~cm} \times$ $30 \mathrm{~cm}$ (Remison, 1978e). At Asaba, the plots were planted on September 14th and September 29th 2005 in Abraka. Seeds that failed to germinate were replaced four days after planting. Thinning to two stands per hole took place, ten days after. Each plot contained 6 rows of 36 cowpea stands. The farms were kept weed free throughout the study period.

Insect collection commenced two weeks after plant emergence, between 8.00 a.m. and 10.00 a.m., every week. Sweep net $(30 \mathrm{~cm}$ diameter and $75 \mathrm{~cm}$ deep) was used to collect insects. Another way insects were collected was by handpicking. Insect collection continued to harvest. All insects collected were preserved and then despatched to the curators at the International Institute of Tropical Agriculture (IITA) Ibadan and Institute of Agricultural Research and Training (AIRT), Ahmadu Bello University, Zaria, Nigeria for identification.

\section{RESULTS AND DISCUSSION}

The insect complex of cowpea during the late planting season at Asaba and Abraka is presented in Table 1. Ten (10) insect orders, 24 families and 39 insect species occurred at Asaba while 8 orders, 23 families and 35 species were encountered at Abraka. The insect orders, number of species and their relative abundance (\%) in each locality are given in Tables 2 and 3. The heteroptera and coleoptera were most dominant at Asaba with relative abundance of 28.2 and $25.6 \%$ respectively. Similar situation was encountered at Abraka. Compared with Abraka, the coleptera were of equal number of species, 10 in each location. However, Asaba had more heteroptera when compared to Abraka. Both locations had the same number of insect species (4) for homoptera and diptera. The least insect species (1) occurred each for thysanoptera and dermaptera at Asaba, while at Abraka, it was thysanoptera with 1 species. Generally, Asaba recorded slightly more insect species (39) than Abraka (35) in the late planting season. Nine insect species recorded at Asaba were absent at Abraka.

They were:

(i). Cryptocephalus gladiatorius Suff (Coleoptera)

(ii). Coptosoma nubila Germ (Heteroptera),

(iii). Cletomorpha lanciger Fab (Heteroptera)

(iv). Helopeltis schoutedeni Reut (Heteroptera)

(v). Halictus sp (Hymenoptera)

(vi). Marasmia trapezalis Guence (lepidoptera)

(vii). Blattela loviventris Sau (Dictyoptera)

(viii). Rhaphiophana nigrifrons Mel (Dictyoptera)

(ix). Chelisoches flavipennis F (Dermaptera)

At Abraka, four insect species recorded on the crop were absent at Asaba in the late season. They were:

(i). Lema coelestina (Coleoptera)

(ii). Phaneroptera nana sparsa Stal (Orthoptera)

(iii). Hymenta recurvalis Fab (Lepidoptera)

(iv). Pseudocreobotra ocellata (Hymenoptera)

Jackai (1983) had reported that not all insect species occurred in all localities; that species vary from region to region. This study confirmed the above report.

The study areas, in the late season recorded the key insect pests of cowpea namely, the cowpea aphid, Aphis craccivora Koch; the flower thrips, Megalurothrips sjostedti Tryb., the legume pod borer, Maruca vitrata Fab. And pod ducking bugs such as C. shadabi, Anoplocnemis curvipes, Mirperus species, Nezara virudula and Aspavia armigera, reported to occur in the main cowpea producing zones of Nigeria (Libby, 1968, Singh and van Emden, 1979; Singh et al., 1983; Jackai, 1985; Jackai and Daoust, 1986; Ogunwolu and Ekefan, 1991) and at Umudike, Southern Nigeria (Emosairue et al, 2004). A. craccivora infestation occurred 2 weeks after planting (WAP) at both locations and population was high (over 300 per stand). This suggests, possible high level of damage, whereby control measures would be required in the study areas as yield losses due to uncontrolled $A$. craccivora could be high. Pod sucking bugs particularly $C$. tomentosicollis were abundant (over 5 bugs/m row) at both locations. The observations of PSBS in the two locations agree with the report of Dina (1982) and IITA (1983) that pod sucking bugs occur abundantly during the late planting season. For meaningful grain yield in these areas, damage to pods and seeds by PSBS, must be checked because uncontrolled infestation of these insects have been reported to cause cowpea losses in the $\begin{array}{llll}\text { magnitude of } & 80 \% & \text { and }\end{array}$ 
Agric. Biol. J. N. Am., 2011, 2(3): 448-453

Table 1:

Insect species on cowpea in the late cropping season in Asaba and Abraka, Delta State

\begin{tabular}{|c|c|c|c|c|c|}
\hline \multicolumn{5}{|c|}{ Locations } & \multirow[b]{3}{*}{ Order } \\
\hline & & Asaba & Abraka & & \\
\hline Order & Family & Insect Species & Insect Species & Family & \\
\hline \multirow{11}{*}{$\begin{array}{r}\text { Coleoptera } \\
\text { ", } \\
, \\
", \\
", \\
", \\
, "\end{array}$} & Chrysomelidae & Ootheca bennigseni Weise & Ootheca bennigseni Weise & Chrysomelidae & Coleoptera \\
\hline & Chrysomelidae & Ootheca mutabilis Sahlberg & Ootheca mutabilis Sahlberg & Chrysomelidae & Coleoptera \\
\hline & Chrysomelidae & Medythia quarterna Fair & Medyethia quarterna Fair & Chrysomelidae & Coleoptera \\
\hline & - & & Lema coelestina & Chrysomelidae & Coleoptera \\
\hline & Chrysomelidae & Cryptocephalus gladiatorius Suff & - & - & - \\
\hline & Curculionidae & Piezotrachelus sp & Piezotrachelus sp & Curculionidae & Coleoptera \\
\hline & Bruchidae & Callosobruchus maculatus F & Callosobruchus maculatus F & Bruchidae & Coleoptera \\
\hline & Ichneumonidae & Nematocerus acerbus (Fst) (Brulle) & Nematocerus acerbus (Fst) (Brulle) & Icheumonidae & Coleoptera \\
\hline & Lagridae & Lagria villosa Fab & Lagria villosa Fab & Lagridae & Coleoptera \\
\hline & Coccinellidae & Cheilomenes Iunata Fab & Cheilomenes Iunata Fab & Coccinellidae & Coleoptera \\
\hline & Meloidae & Mylabris sp & Mylabris sp & Meliodae & Coleoptera \\
\hline \multirow{11}{*}{$\begin{array}{c}\text { Heteroptera } \\
\text { ", }\end{array}$} & Plataspidae & Coptosoma nubila Germ & - & - & - \\
\hline & Pentatomidae & Nezera viridura L. & Nezara virudula L & Pentatomidae & Hepteroptera \\
\hline & Plataspidae & Aspavia armigara Fab & Aspavia armigara Fab & Pentatomidae & Heteroptera \\
\hline & Pentatomidae & Dysdercus superstitiosus F & Dysdercus superstitiosus F & Coreidae & Heteroptera \\
\hline & Pyrhocoridae & Cletomorpha lanciger Fab. & - & - & - \\
\hline & Coreidae & Riptortus dentipes Fab. & Riptortus dentipes Fab & Coreidae & Heteroptera \\
\hline & Coreidae & Clavigralla tomentosicollis Stal. & Clavigralla tomentosicollis Stal. & Coreidae & Heteroptera \\
\hline & Coreidae & Clavigralla shadabi Dolling & Clavigralla shadabi Dolling & Coreidae & Heteroptera \\
\hline & - & Anoplocnemis curvipes Fab & Anoplocnemis curvipes Fab & Coreidae & Heteroptera \\
\hline & - & Mirperus jaculus Thunb. & Mirperus jaculus Thunb. & Coreidae & Heteroptera \\
\hline & - & - & Deraeocoris martinini (Puton) & Pentatomidae & Heteroptera \\
\hline
\end{tabular}

- indicates insect's absence 
Agric. Biol. J. N. Am., 2011, 2(3): 448-453

Table 1 Cont: Insect species on cowpea in the late cropping season in Asaba and Abraka, Delta State

\begin{tabular}{|c|c|c|c|c|c|}
\hline \multicolumn{6}{|c|}{ Locations } \\
\hline Order & Family & Insect Species & Insect Species & Family & Order \\
\hline ," & Miridae & Helopeltis schoutedeni Reut & - & - & - \\
\hline ," & Coreidae & Mirperus jaculus & - & - & - \\
\hline Homoptera & Cicadellidae & Tettigellin sp & Tettigellin sp & Cicadellidae & Homoptera \\
\hline ," & Cicadellidae & Hiltus $s p$ & Hiltus $s p$ & Cicadellidae & Homoptera \\
\hline , & Cicadellidae & Selenocephalus varius Sign & Selenocephalus varius Sign & Cicadellidae & Homoptera \\
\hline ", & Aphidae & Aphis craccivora Koch & Aphis craccivora Koch & Aphidae & Homoptera \\
\hline Diptera & Muscidae & Atherigona $s p$ & Atherigona $s p$ & - & - \\
\hline , & Diopsidae & Diopsis collaris WSTW & Diopsis collaris WSTW & Diopsidae & Diptera \\
\hline ," & Platysromatidae & Plagiosterno pterina westermanni $(\mathrm{H})$ & Plagiosternopterina westermanni $(\mathrm{H})$ & Platystomatidae & Diptera \\
\hline ", & Asilidae & lewinella $s p$ & lewinella $s p$ & Asilidae & Diptera \\
\hline Hymonoptera & Apidae & Halictus $s p$ & - & - & - \\
\hline , & Apidae & Xylocopa olivacca Fab & Xylocopa olivacea Fab & Formidae & Hymenoptera \\
\hline & - & - & Pseudo creeobotra ocellata & Formidae & Hymenoptera \\
\hline Orthoptera & Pyrgomorphidae & Pyrgomorpha vignaudi Guer & Pyrgomorpha vignaudi Guer & Pyrgomorphidae & Orthoptera \\
\hline , & Pyrgomorphidae & Zonocerus variegatus & Zonocerus variegatus & Pyrgomorphidae & Orthoptera \\
\hline & - & - & Phaneroptera nana sparsa Stal & Pyrgomorphidae & Orthoptera \\
\hline Lonidont" & - & - & & & \\
\hline Lepidoptera & Pyralidae & Maruca vitrata Fab & Maruca vitrata Fab. & Pyralidae & Lepidoptera \\
\hline ," & - & Marasmia trapezalis Guence & - & - & - \\
\hline & - & - & Hymentarecurvalis Fab & Pyralidae & Lepodoptera \\
\hline Dictyoptera & Blattidae Blattella & loviventris Sau & - & & \\
\hline ", & Dictyopharidae & Rhaphiophana nigrifrons (Mel) & - & - & - \\
\hline Thysanoptera & Thripidae & Megalurothrips sjostedti Trb & Megalurothrips sjostedti Trb & Thripidae & Thysanoptera \\
\hline Demaptera & Opisthocosmiidae & Chelisoches flavipennis F. & - & - & - \\
\hline
\end{tabular}

- Insect's absence 
Agric. Biol. J. N. Am., 2011, 2(3): 448-453

Table 2: Insect orders, number of species and relative abundance (\%) in the late season at Asaba

\begin{tabular}{|l|c|c|}
\hline Insect order & Number of species & Relative abundance (\%) \\
\hline Heteroptera/Hemiptera & 11 & 28.2 \\
Coleoptera & 10 & 25.6 \\
Homoptera/Hemiptera & 4 & 10.3 \\
Diptera & 4 & 10.3 \\
Hymenoptera & 2 & 5.1 \\
Lepidoptera & 2 & 5.1 \\
Orthoptera & 2 & 5.1 \\
Dictyoptera & 2 & 5.1 \\
Thysanoptera & 1 & 2.6 \\
Dermaptera & 1 & 2.6 \\
\hline
\end{tabular}

Table 3: Insect orders, number of species and relative abundance (\%) in the late season at Abraka

\begin{tabular}{|l|c|c|}
\hline Insect order & Number of species & Relative abundance (\%) \\
\hline Coleoptera & 10 & 28.6 \\
Heteroptera/Hemiptera & 9 & 25.7 \\
Homoptera/Hemiptera & 4 & 11.1 \\
Diptera & 4 & 11.1 \\
Orthoptera & 3 & 8.6 \\
Lepidoptera & 2 & 5.7 \\
Hymenoptera & 2 & 5.7 \\
Thysanoptera & 1 & 2.9 \\
\hline
\end{tabular}

95\% for pod and seed yield respectively (Ogunwolu and Ekefan, 1991). Flower bud thrips, Magalurothrips sjostedti and the legume pod borer, Maruca vitrata population were generally low at both locations (Tables 2 and 3 ).

The aim of this study is to acquaint cowpea farmers intending to embark on large scale cultivation of the crop in these areas of likely insect pests problem.

\section{CONCLUSION}

Ootheca mutabilis, Aphis craccivora, Megalurothrips sjostedti, Maruca vitrata and coreid bugs such as Cravigralla tomentosicollis, Anoplocnemis curvipes, C. shadabi, Aspavia armigara, Nezara virudula, Mirperus jaculus were the key insect pests identified in the areas. Coreid bug population was high at both locations and would require control. More insect species occurred at Asaba than Abraka in the late season.

\section{ACKNOWLEDGEMENTS}

My thanks to the curators at the International Institute of Tropical Agriculture (IITA), Ibadan, Nigeria and Institute of Agricultural Research and Training (IART), Ahmadu Bello University, Zaria, Nigeria, who identified the insect species of cowpea from the study area.

\section{REFERENCES}

Alabi, O.Y., Odebiyi, J.A. and Jackai, L.E.N. (2003) Field evaluation of cowpea cultivars (Vigna unguiculata (L) Walp.) for resistance to flower bud thrips (Megalurothrips sjostedti Trybom) Thysanoptera: Thripidae) International Journal of Pest Management. 49 (4), 287-291

Bittenbender, H.C., Barret, R.P. and Indire-lavusa, B.M. (1984). Beans and Cowpeas as leaf vegetables and 
grain legumes. Monograph no 1 Bean/Cowpea collaborative research support program, East Lansing, MI.

Dina, S. O. (1982) Interactions between rate, spray interval and number of applications of the synthetic pyrethroid Decis in Cowpea (Vigna unguiculata) pest control. J. Agric, Camb. 99. 471-478

Ejiga, N.O. (1979) The efficiency of the indigenous food grain marketing systems in Nigeria, Savannah Dec., 8 (2), $70-83$

Emosairue, S.O., G.E. Nwofia, S.B.A. Umuetok (2004). Observation on the Insect complex associated with cowpea (Vigna unguiculata (L.) Walk in Umudike, South-eastern Nigeria. J. Sustain. Agric. Environ. 6(1):38-43.

FOS (1995) Annual Abstract of statistics, Lagos, Nigeria.

IITA (1983) Annual Report for 1982. Ibadan, Nigeria

IITA (1984) Annual Report for 1982. Ibadan, Nigeria

Jackai, L. E. N. (1983) Efficacy of insecticide applications at different times of day against the legume pod borer, Maruca vitrata (Fab) (Lepidoptera: pyralidae) on cowpea in Nigeria. Protection Ecology 5. 245-251.

Jackai, L.E.N. (1985) Cowpea Entomology Research at IITA and its impact on food production in the tropics. Nigeria J. Ent. 6, 87-97

Jackai, L.E.N. and Daoust, R.A. (1986). Insect pests of cowpeas. Annual Review of Entomology 3195119

Jackai, L.E.N., J.M.F. Roberts and S.R. Singh (1988). Cowpea seed treatment with carbosulfan: potential for control of seedling pests. Crop Protection Vol. 7, December 1988, 384-390.
Job, T.A., Maner, J.H. and Buitrago, J. (1983) Nigerian journal of Nutritional Sciences, 4 (1), 29-34

Libby, J.L. (1968). Insect pests of Nigerian Crops. University of Wisconsin Res. Bull. No. 269:69pp.

Ogunwola, E,O. and Ekefan, E.J., (1991). Pod-sucking bug damage to cowpea in relation to time and frequency of insecticide application in the Southern Guinea Savanna zone of Nigeria. JAT Vol. 4 No. 2, 1-9.

Okigbo, B.N. (1978) Grain legumes in the agriculture of the tropics. In Pests of Grain legumes Ecology and control (Edited by Singh S.R. Van Emden H.E. and Taylor T.A) Academic Press, Inc., New York.

Rachie, K.O. (1985) Introduction. P. xxi xxviii. In: S.R. Singh and K.O. Rachie (eds). Cowpea research, production and utilization. Wiley New York.

Remison, S.U. (1978e) Cowpea agronomy works at National Cereals Research Institute. Paper presented at the 1st National meeting. On development of package. Recommendations for legume crops at N.C.R.I, Ibadan, 7-8 February.

Singh, S.R. and Jackai, L.E.N. (1985) Insect pests of cowpeas in Africa: their life cycle, economic importance and potential for control. Pages 217-231 in cowpea research production and utilization, edited by S.R. Singh and K.O. Rachie. John Wiley and Sons N.Y.

Singh, S.R. and van Emden, H.F. (1979) Insect pests of grain legumes. Annual Reviews of Entomology 24, pp. 255-278.

Taylor, T.A. (1964). The field pest problems on cowpea. (Vigna sinensis L.) in Southern Nigeria, Grower Producer3 (2). 